\title{
A WISE FOOL'S ANECDOTAL CYCLE IN MALTA: A REAPPRAISAL
}

\author{
Gorg(George) Mifsud-Chircop
}

\begin{abstract}
The predominant anti-hero in Maltese folk narrative is Gahan (/'djahan/). He is the wise fool, popular with one and all in contemporary Malta. However, in the first half of the twentieth century there was a historical undercurrent which, through children's literature, has manipulated and bowdlerised the discursive richness of Maltese folk culture to the extent of framing Gahan as a "light-headed" fool, at times defining his anecdotes, brimming with sagacity, slyness, guile, cheats and deceits, as "stupidities". It is the aim of this article to show how through his research and publications the author has challenged this pseudo-scientific assertion which has been crystallised in the native language of the Maltese archipelago. Humour is not only a device to uphold interest in the tale. Above all it facilitates the comprehension of the progression of events, thus heightening effectiveness and efficiency of the narration. Although artificially indulging in anti-social behaviour, the Maltese wise fool semantically also takes the role of a social critic in his farce as well as that of an interceder for the injured and the insulted. He is a poetic vehicle to express folk wisdom, often putting the fool's cap on himself. His tales are a kind of "ritual of rebellion" which represents an institutionalized way of expressing antagonism towards authority. His anecdotes, better known in Maltese as praspar (/p'ra:spar/), constitute the temporary subversion of a conscious, symbolic order in the interests of a pleasure-oriented subconscious. Gahan's duty is to change chaos to its inverse, cosmos, social disorder to order, the indistinct to the distinct, disequilibrium to equilibrium, to create life and the symbolic universe of our life.
\end{abstract}

Key words: Maltese folklore, folk narrative, Gahan, folk culture

The predominant anti-hero in Maltese folk narrative is Gahan (/'djahan/). He is the wise fool, popular with one and all in contemporary Malta. He is the epitome of Maltese verbal wisdom and humour. The subjective and definite colouring of Gahan's anecdotes is imbued with typical Mediterranean narrators' humour which often takes the form of a negative tendency. But it is a tendency that springs from the inclination and will to laugh at oneself and the world at large, an ironical bent toward contradiction and debunking. Humour is not only a device to uphold interest in the tale. It also facilitates the comprehension of the progression of events, thus heightening effectiveness and efficiency of the narration. 
Due to lack of scientific fieldwork research, many in Malta openly declare and write in their "desk analyses" that Gahan is dead, thus giving no attention to ethnic or native analysis, framing him as a "light-headed" fool and his anecdotes, brimming with sagacity, slyness, guiles, cheats and deceits, have been defined as stupidities by a Maltese academic. There has been a historical undercurrent since the first half of the twentieth century which, through children's literature, has manipulated and bowdlerised the discoursive richness of Maltese folk culture on Gahan. It is the aim of this paper to show how through my research and publications I strongly disagree with this pseudo-scientific assertion which has been crystallised in Maltese, the native language of the Maltese archipelago.

Although artificially indulging in anti-social behaviour, the Maltese wise fool semantically also takes the role of a social critic in his farcical behaviour as well as that of an interceder for the injured and the insulted. He is a poetic vehicle to express folk wisdom, often putting on himself the fool's cap. His tales are a kind of "ritual of rebellion" which represents an institutionalized way of expressing antagonism towards authority. His anecdotes, better known in Maltese as praspar (/p'ra:spar/), constitute the temporary subversion of a conscious, symbolic order in the interests of a pleasure-oriented subconscious. Gahan's duty is to change chaos to its inverse, cosmos, social disorder to order, the indistinct to the distinct, disequilibrium to equilibrium, to create life and the symbolic universe of our life. Understandably different readings can be located in the same text.

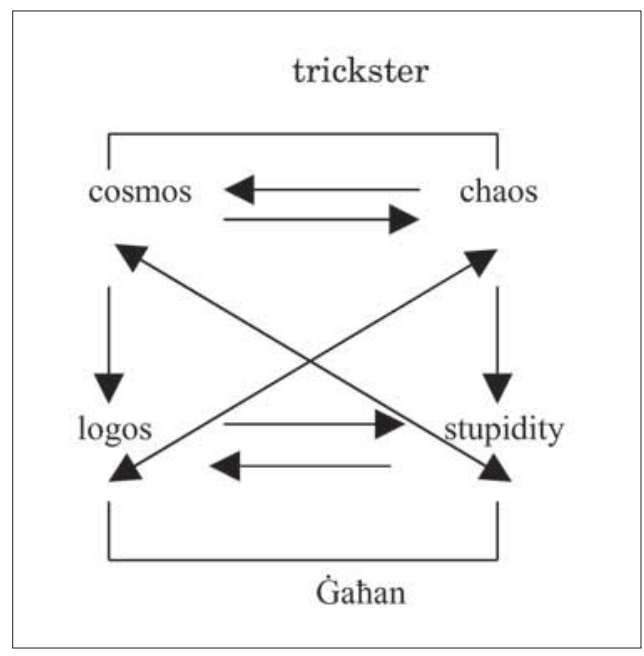

Figure 1. The $\dot{G}$ ahan code in Maltese narrative. 


\section{GAHAN IN A NATIONAL CHILDREN'S ANTHOLOGY}

The folk narrative personality of Gahan was not new in the first quarter of twentieth-century Malta. Italian professor Luigi Bonelli (1865-1947), and Germans Hans Stumme (1864-1936) and Bertha Ilg (1881-1965) had already published 17 ethnotexts in Italian, Maltese, and German, respectively, where Gahan plays the dramatic narrative role of the (wise) fool in various types (Bonelli 1895; 1897: 53-98; 1899: 37-70; Stumme 1904a; 1904b; Ilg 1906). There was also a newspaper in Maltese by the name $\dot{G} a$ han, published in 1846-1848 and 18541861. Ilg collected thirty-six schwänke on Kemuziell (1995), a variant of Gahan in early twentieth-century Malta (1906-1912).

In 1920, Albert V. Laferla (1887-1943) took office as Director of Elementary Schools, and thir-

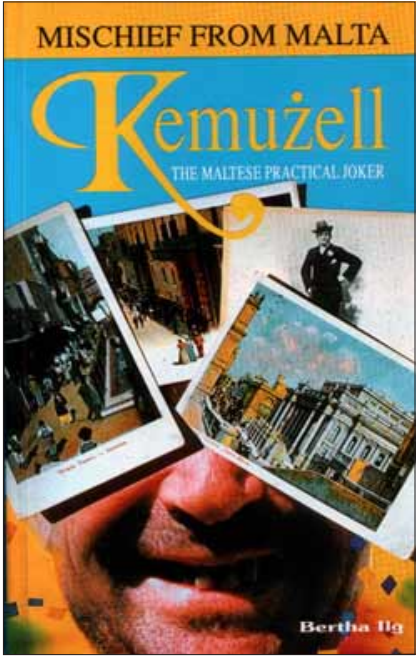

Figure 2. Kemużell (1995), Bertha Ilg's anthology of anecdotes.

Table 1. Pre-1910 texts featuring $\dot{G}$ ahan in his narrative role of the (wise) fool.

\begin{tabular}{|l|l|}
\hline Types $^{\mathbf{i}}$ & Texts \\
\hline ATU 1009 & "Pull Door Behind You". Ilg nos. 89, 93. \\
\hline$* 1010$ A & Looking for Firewood. Stumme no. 16. \\
\hline ATU 1013 & Bathing the Child. Stumme no. 16. \\
\hline ATU 1143 & Ginning the Giants on the Spinning-Wheel. Bonelli no. 8. \\
\hline ATU 1200 & The Sowing of Pigs. Ilg no. 95. \\
\hline *1211 & Enough Fat. Ilg no. 96. \\
\hline ATU 1349* & $\begin{array}{l}\text { "My Portion of Urine is on Top!" Bonelli no. 7; Pony Hidden } \\
\text { away under Bed. Stumme no. 15. }\end{array}$ \\
\hline ATU 1386 & Meat as Food for Cabbage. Ilg nos. 90, 96. \\
\hline ATU 1415 & A Large Sum of Money for a Diseased Pony. Stumme no. 15. \\
\hline ATU 1534D* & Sham Dumb Man Wins Suit. Ilg no. 97. \\
\hline ATU 1536B & The Three Drowned Capuchins. Stumme no. 28. \\
\hline ATU 1540A* & Trickster Taking Sow to the Wedding. Stumme no. 15. \\
\hline ATU 1558 & Welcome to the Clothes. Bonelli no. 7; Ilg no. 92. \\
\hline *1564A 1 & Descending from Top to Bottom and Vice-Versa. Ilg no. 94. \\
\hline ATU 1643 & The Broken Statue. Bonelli no. 9; Ilg no. 91; Stumme no. 15. \\
\hline ATU 1655 & $\begin{array}{l}\text { The Profitable Exchange. Bonelli no. 9; Ilg no. 91; Stumme nos. } \\
\text { 25, 35. }\end{array}$ \\
\hline ATU 1693 & Where People Do not Sit. Stumme no. 15. \\
\hline ATU 1696 & Literally Followed Instructions. Bonelli no. 6; Stumme no. 15. \\
\hline
\end{tabular}




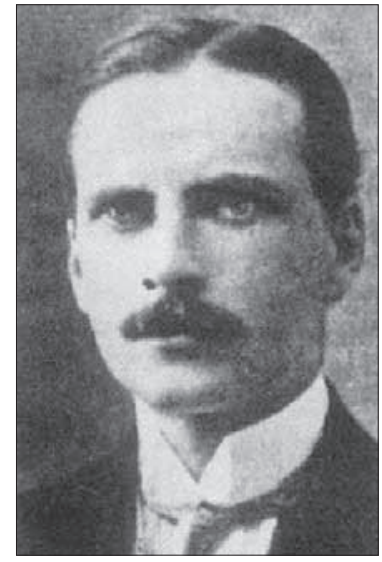

Figure 3. Emmanuel Albert V. Laferla (1887-1943). Photo courtesy of G. MifsudChircop.

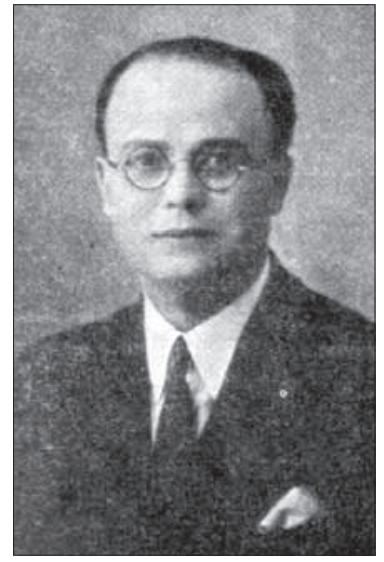

Figure 4. E. B. Vella (18991946). Photo courtesy of the Vella family.

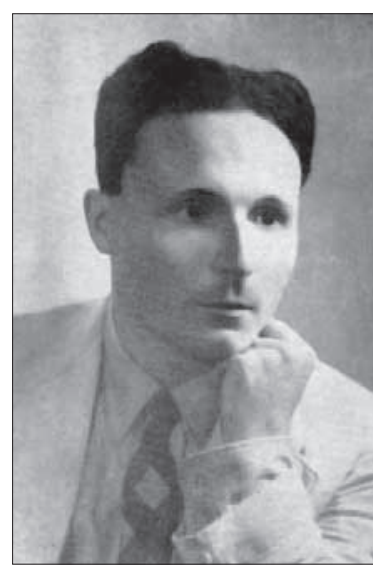

Figure 5. Maltese Romantist poet $\dot{G}$ org Pisani. Photo courtesy of the Pisani family.

teen years later as Director of Education in Malta, ${ }^{2}$ then under British Rule. He had various reforms in the offing (Zammit-Mangion 1998: 15), including the teaching of Maltese which historically were of utmost importance in the background of the Language Question during the political upheaval of the time (L-Istorja ta' l-Edukazzjoni f'Malta 2000: 79-81). ${ }^{3}$ Here Laferla found the support of Benjamin Vella (1899-1946), an Assistant Inspector of Maltese, ${ }^{4}$ who delegated the task to various teachers, authors and collaborators to write, collate and publish Gabra ta' Ward [lit. 'A Collection of Roses', 1934-36, 6 vols], the new anthology of six Maltese readers for all primary schools.

Vella was the editor (Zammit-Mangion 1998: 53), and his strong personality defined the cultural perspective of this series. Vella's contribution towards the implementation of a strategic policy in the learning of Maltese has not been scientifically researched as yet. Going by the words of Gorg Pisani (1909-99), one of the members who were commissioned by Vella to write poems for his anthology, it is clear that the choice was absolutely in Vella's hands

... Kienu se johor gu 1-Ġabra ta' Ward, ... ghalhekk il-poeti gew mitluba jibag htu [sic] xi xog hlijiet tag hhom biex dawn ikunu jistg hu jigu ppubblikati f'din is-sensiela... Darba Pisani ltaqa' ma' E. B. Vella u dan talbu biex jipprova jikteb xi poe z̈ji g hat-tfal, g hax dawk li kien irc̈ieva ming hand xi poeti ma tantx kienu addattati g hat-tfal.

Ghall-ewwel Pisani ma kienx ser jaćcetta bic்a xog hol bhal din, ghax beda jiddubita jekk kienx kapaci jidhol ghaliha. E. B. Vella ghamillu l-kuragg u Pisani wieg hdu li jipprova jikteb xi poeżji... 
... [U] meta kellu gabra ta' tletin poez̈ja mar bihom ghand E. B. Vella li malli qrahom mill-ewwel ghogbuh, ghax fihom hass dik ix-xi haga li kienet nieqsa mill-poeżji ta' poeti ohrajn u li kienet ta' htiega kbira f'din ix-xorta ta' poeziji.

[... Gabra ta' Ward was introduced to be published ... consequently poets were requested to contribute some works for publication in this series ... Once Pisani met E. B. Vella who asked him to write some poems for children because what he had received so far was not suitable for children.

Pisani had not meant to accept such a task because he thought he might not have been up to it. On E. B. Vella's encouragement Pisani promised he would try to write some pieces.

... When he had a collection of thirty poems he took them to E. B. Vella who liked them immediately because he found in them what was missing in the other poets' work, something which was essential in this kind of poetry.] (See Galea 1976: 163-164, 8.)

Two dominant aspects in his editorial choice are a pro-colonial worldview and a class-levelled society in Malta, ${ }^{5}$ including indoctrination of young readers to cherish their loyalty to the British Crown (Vella 1936c: 7). ${ }^{6}$ It is this anthology which perpetuated for the next generations the narrowed picture of Gahan in three anecdotes: Ǵa han u l-Bieb (lit. 'Gahan and the Door', ATU 1009), Ga han u l-Flieles (lit. 'Ġahan and the Chickens', ATU 1696), and Ga han u l-Fanär [lit. 'Gahan and the Pig', ATU 1386].

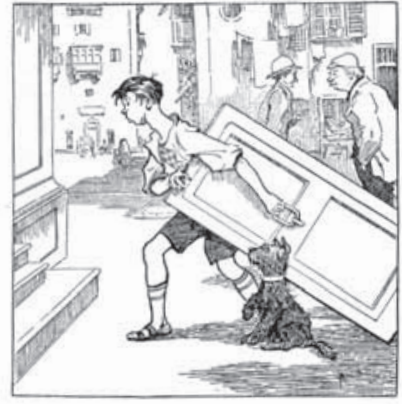

21. GAHAN U L-BIEB

Kien il-Hadd, u omm Gahan riedet tmur il-quddies kmieni. Gahan kien ihobb il-friex u ma riedx ihalli ${ }_{38}^{8}$

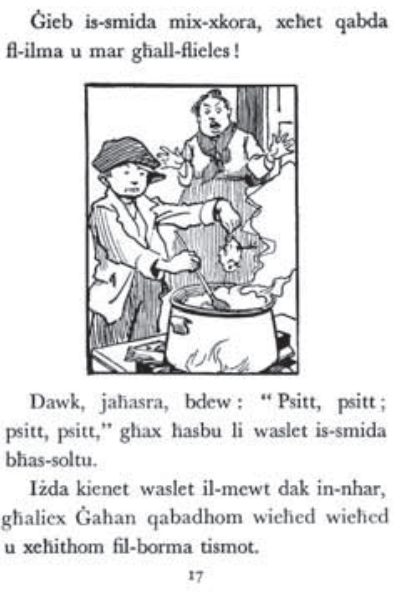

"Oqghod, naf x'naghmel. Hemm ilhanżir ghall-qtil, halli nillestih biex ommi tarah lest meta tigi lura."

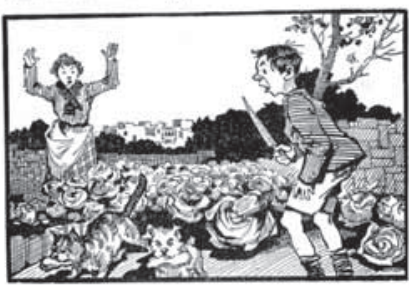

Mar xtara ftit xaham, dellku mal-hanžir, qattghu bćjjec̀ u qieghidu bičca fuq kull kabočca fil-g̉nien.

$\mathrm{X}$ 'hin dalam ommu giet id-dar, u hekk kif dahlet tisma' aghjat kbir ta' qtates u klieb fil-ġnien. Qabdet l-imnara u marret 56

Figure 6. Three Gahan anecdotes presenting anti-hero as a "light-headed fool". Courtesy of G. Mifsud-Chircop. 
In the post-war period right to Independence (1964) from the British, methodology in the teaching of Maltese remained unchanged in spite of a cultural revival in the arts in The Sixties. Here Zammit-Mangion does not mince words:

The curriculum and the methods of instruction, though of a high standard as developed by $\operatorname{Dr}$ A. V. Laferla during his directorship, had to be changed in order to suit new needs: indeed, the whole thinking about education and its philosophy had to change, partly to meet the needs of the children themselves and partly to meet the demands of Malta's postwar society ... [However,] in the educational field, officially at least, matters did not change much [after Independence] and there was hardly any change in the curricula, syllabi and textbooks... (1992: 55, 77).

When the old anthology was to be replaced by the new series Id-Denfil ['The Dolphin', 5 vols; Camilleri et al. 1974), the same frame of mind persisted in the new editors as far as Gahan is concerned, though this time two editorial boards of teachers drew the selections of the anthology for all public primary schools (Fenech 2003: 174, 176). ${ }^{7}$ Here two same anecdotes depict Gahan only as a halfwit young boy behaving like a fool (the words il-batnan ta' Ga han

Table 2. The two anecdotes which have narrowed Gahan to a "light-headed" fool. (1 - Vella 1936d: 27-28 and Puli et al. 1981: 24-25; 2 - Vella 1935: 8-10/Id-Denfil 1985: 13-15).

1 "Ġaћan u l-Bieb"

2 "Ǵăan u l-Flieles" / "Imsejkna Flieles!”

[lit. 'this fool of a Ġahan'] in Maltese explains it all (Vella 1935: 10)), are reprinted verbatim, except for an unhealthy change in the title of the second story which does not reflect the popular name of the narrative, some changes in punctuation marks and a blunt censorship of a short sentence in the second text:

Table 3. An example of editorial censorship on an old text.

\begin{tabular}{|l|l|}
\hline \multicolumn{1}{|c|}{ Gabra ta' Ward, 1935} & \multicolumn{1}{|c|}{ Id-Denfil, 1974 } \\
\hline $\begin{array}{l}\text { "Qridtli l-flieles kollha } \text { u dalwaqt neqred } \\
\text { lilek!" }\end{array}$ & "Qridtli l-flieles kollha!" \\
\hline $\begin{array}{l}\text { Transl: "You've killed all my chickens } \\
\text { and I'll soon be putting an end to you?" }\end{array}$ & Transl: "You've killed all my chicks!" \\
\hline
\end{tabular}


Typical narratorial comments to chastise Gahan to the maximum run as follows in the two texts:

Table 4. Narratorial comments to chastise Gahan

\begin{tabular}{|c|c|}
\hline $\begin{array}{l}\text { jaћseb kemm daћku n- } \\
\text { w lil Ġahan ikarkar il- } \\
\text { (1) }\end{array}$ & $\begin{array}{l}\text { they saw } \\
\text { door! }\end{array}$ \\
\hline $\begin{array}{l}\text { tal-hin u Ġahan beda biex } \\
\text { k li qaltlu ommu. Imma } \\
\text { Ta' Ġaћan li kien. (2) }\end{array}$ & $\begin{array}{r}\text { 2- After a } \\
\text { his m } \\
\text { By bei }\end{array}$ \\
\hline kien & $\begin{array}{r}\mathbf{3}-\ldots \\
\min \\
\end{array}$ \\
\hline $\begin{array}{r}4-" \\
\text { ti }\end{array}$ & $\begin{array}{r}4-{ }^{2 Y o} \\
\text { beca }\end{array}$ \\
\hline $\begin{array}{r}-{ }^{-} \mathrm{Ra} \\
\mathrm{ims}\end{array}$ & $5-$ - $\mathrm{He}$ \\
\hline
\end{tabular}

No attempt was made by the new editors to present folk narratives to the new generations of students with a better and "objective" selection from contemporary published texts. It is only recently that these lacunae have been balanced by my literary interpretations (Table 5, nos. 1-5) of various Gahan anecdotes in my publications and also by a critique (Table 5, no. 6) of a misinterpretation of the wise fool in Gahan as developed by the contemporary foremost Maltese dramatist Francis Ebejer (1925-1993) in his play Il-Gahan ta' Bingemma ['The Gahan of Bingemma', 1985].

Table 5. Narrativizing Gahan as the (wise) fool.

\begin{tabular}{|c|c|}
\hline 1 & $\begin{array}{l}\text { Il-Praspar ta' Gaћan [Gaћan Anecdotes]. Malta: Gulf Publishing, 1980, } \\
\text { 1982, } 1989 .\end{array}$ \\
\hline 2 & $\begin{array}{l}\dot{G} a \hbar a n \text { u } l \text {-Ggant Gulija [Ġahan and Giant Goliath]. Malta: Gulf Pub- } \\
\text { lishing } 1981 .\end{array}$ \\
\hline 3 & $\begin{array}{l}\text { Aktar mill-Praspar ta' Ga han [Further Gahan Anecdotes]. Malta: Gulf } \\
\text { Publishing } 1983 .\end{array}$ \\
\hline 4 & 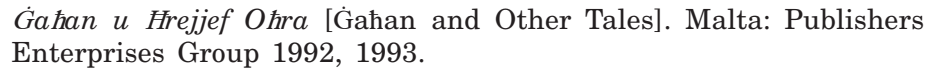 \\
\hline 5 & 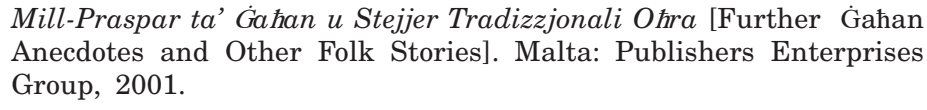 \\
\hline 6 & $\begin{array}{l}\text { "Gahan fid-Dramm ta' Ebejer u n-Narrattiva Folkloristika" [Gahan in } \\
\text { Folk Narrative and in Ebejer's Play], Fora Melitensia, 2, Malta: The } \\
\text { University of Malta, the Department of Maltese, Junior College, } \\
\text { 2005, pp. 26-38. }\end{array}$ \\
\hline
\end{tabular}


Moreover, three texts (from No. 5) - "Il-Bajd Iebes" [The Hard-Boiled Eggs, ATU 821B] (Cutajar 2002: 20-21), "It-Tifla tal-Lenbija" [The Daughter of the Kneading Pan, ATU 1592B] (Cutajar 2002: 111-114) and "Il-Prezz tal-Hmar" [The Price for the Donkey] (Cutajar 2004: 20-21) - have been included in a sequel to Il-Gojjin, entitled Gojjin Ie hor (2002-2004), on its editor's initiative.

In my critique, I refer to Ebejer's publication The Bilingual Writer (Mediterranean: Maltese and English) as Janus (Malta, 1989) where he defines Gahan in his play as ... the Maltese variant of a nine centuries-old mythical clever-idiot ... (Ebejer 1989: 18; see also Briffa 2002: 43). Ebejer disagrees with those who read only one facet of Ġahan's narrative role, editors included:

"U eh, bil haqq, dak li qalu fuqi dwar ommi u knisja u bieb u mhux bieb, kollu minnu. Imma, jahasra, u holl xaghrek u gib iż-żejt, kemm kien hawn li fehmu sew x'kien l-ghan tieghi dak in-nhar? Kif ma setghux jifhmuni! Qishom, hekk ... kapaci biss biex jifhmu sa dak li jidher minn barra u li ma jkun jehtieg l-ebda thabbil il-moht. Ajma, mur hawwadlu rasu lillMalti b'xi haga li majkunx imdorri biha mill-anqas ghall-ahћar mitt sena!" (Author's emphasis).

[And, indeed, what has been said about me, my mother, the church, the door and not what was all true. But alas, you'll be in for trouble, if you'll try to guess how many really understand the import of my story then. How could they have misunderstood me! It seems thus ... as if they can only understand what is only apparent and what need be given no thought. Beware of trying to unsettle a Maltese person's way of thinking by something which he hasn't been used to for at least one hundred years!] (Briffa 2002: 45).

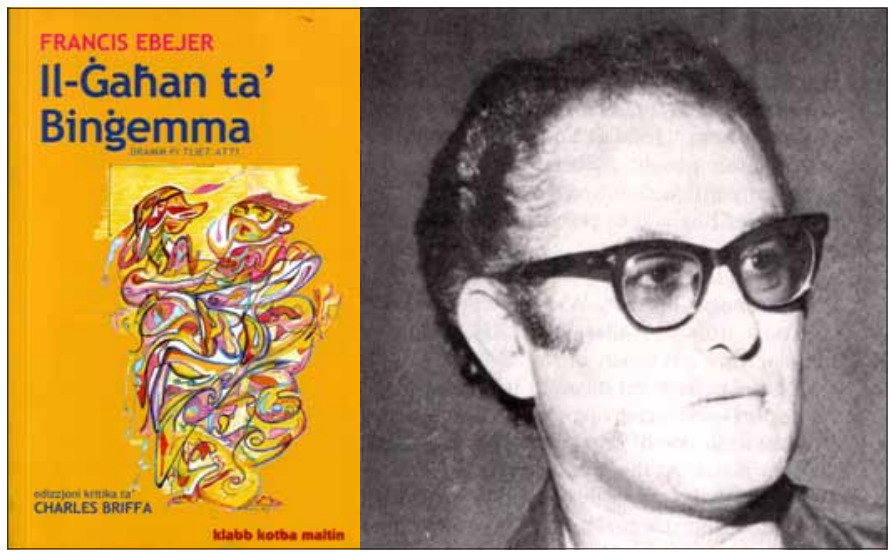

Figure 7. Contemporary Maltese playwright Francis Ebejer (1925-1993) and his play IlGahan ta' Bingemma (1985). Courtesy of the Ebejer family. 
In his $\dot{G}$ han, Ebejer projects the allegory of the modern Maltese young man who has to discover his Maltese representative of Maltese society during the Arab and Norman identity at a time of transition in contemporary post-Independent Malta, as well as the Occupation of Malta (870 AD-1243 AD), another transitory period.

In the pre-1930s we have ample evidence that both sides of Gahan's personality were narrativized (see Table 1). As a result of my ethnographic fieldwork in the past thirty years I can confirm that they still are. However, the education system in the Maltese Islands for the past seventy years has narrowed down drastically the narrative semantics of Gahan, negatively influencing the proverbial phraseology on Gahan. This indirect bowdlerization was further sustained by Aldo Farini's secondary school anthology in Italian Fiabe, leggende e tradizioni maltesi (Malta, 1934-1936) which unequivocally projects Gahan as an idiot (in

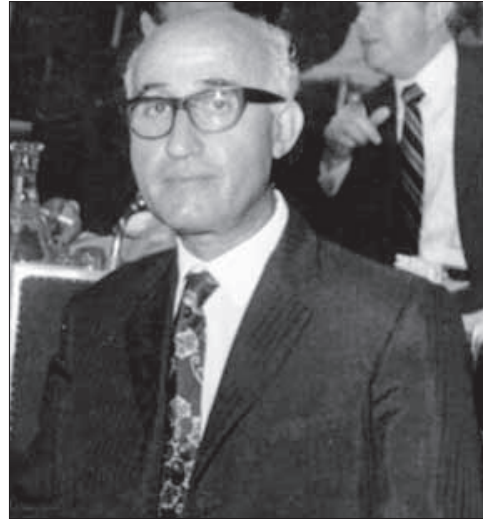

Figure 8. Gużè Cassar-Pullicino. Courtesy of the Cassar-Pullicino family. nine tale types) to teenage students from the upper levels of society, thus with a psycho-sociological import that he is to be identified with the lower classes! In contrast there are various ethno-poetic anecdotes which focus on his anti-heroic philosophy, as recorded by the late Gużè Cassar-Pullicino (1921-2005) in his anthology Stejjer ta'Niesna [Stories of Our People, 1967], ${ }^{8}$ Anton F. Attard in his Hrejjef minn Ghawdex [Tales from Gozo, 1970], and my research and publications (Mifsud-Chircop mss).

There are other examples of gross misinterpretations on Gahan sprinkled with misconceptions and incongruities.

\section{DRAMATIC INTERPRETATIONS}

Dramatic interpretations of my Gahan literary tales in Gahan u Frejjef Otra ['Ġahan and Other Tales'] (1992, 1995) were staged on 4-5 August 1995. This version was hailed as a discovery and revival of Gahan, as if my published literary treatments of these anecdotes since 1980 (Mifsud-Chircop 1980, 1981, 1982 , 1983) were non-existent - sales of my book had run into a couple of thousand, which is quite uncommon in our small market. I feel I was unjustly criticised by the leading [The Times of Malta] drama critic, Paul Xuereb, at having redefined and mishandled the Maltese anti-hero as an adult - the reason being that, as I have already explained, in Maltese primary school text- 
Table 6. Gahan as the fool vs Gahan the wise fool

\begin{tabular}{|c|c|}
\hline $\begin{array}{c}\text { Ġałan the fool, } \\
\text { according to proverbial phraseology }\end{array}$ & $\begin{array}{l}\text { AT Types of Gahan the fool, in } \\
\text { Farini's translations and adaptations } \\
\end{array}$ \\
\hline 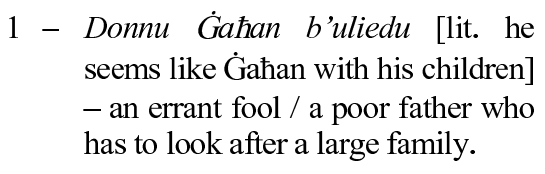 & $\begin{array}{r}2-1229 * . \text { Lifting Beans } \\
\text { Boiling water (I } 2\end{array}$ \\
\hline 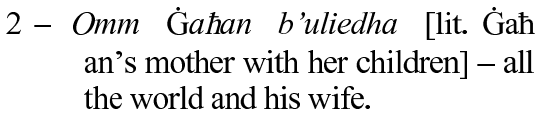 & $3-* 1260 \mathrm{~A}_{1}$. Borrowing the Cooking Pot \\
\hline 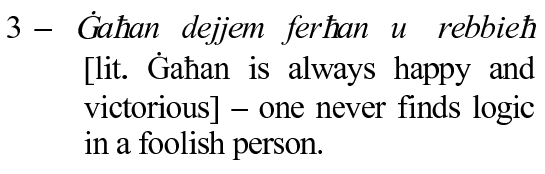 & $4-* 1260 A_{2}$. Quick-lime for Salt. (I 20) \\
\hline 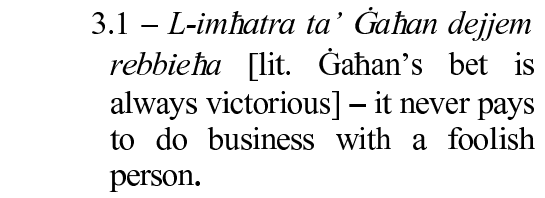 & $\begin{array}{l}6 \text { - 1319*. Drunkard Mistaken for Cock } \\
\text { (I 89-98) }\end{array}$ \\
\hline $\begin{array}{l}4 \text { - Kemm / x'int Ǵaћan! [lit. How / } \\
\text { what a Gahan are you!] - how silly } \\
\text { / what a fool you are! }\end{array}$ & 7 - 1381C. The Goat in Well (I 92-99) \\
\hline $\begin{array}{l}5 \text { - La tkunx } \dot{G} a \hbar a n \text { [lit. Don't be a } \\
\text { Gaћan] - don't be an ass. }\end{array}$ & $\begin{array}{l}8-* 1415 B \text {. A Horse for a Penny (I } 12- \\
15 \text { ) }\end{array}$ \\
\hline 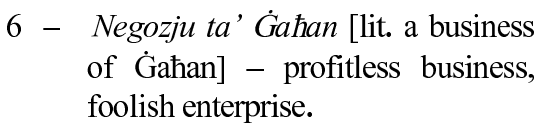 & $\begin{array}{l}9 \text { - 1693. "Do not Make Too Much } \\
\text { Noise" (I 17-18) }\end{array}$ \\
\hline 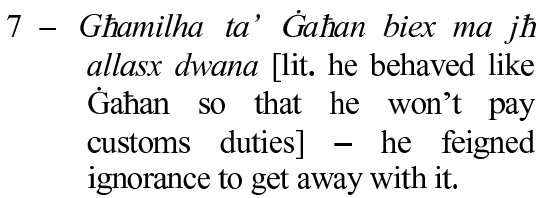 & \\
\hline
\end{tabular}

Table 7. Gahan, the wise fool according to Cassar-Pullicino's (1967), Attard's (1970) and Mifsud-Chircop's recorded texts.

\begin{tabular}{|l|l|}
\hline \multicolumn{2}{|c|}{$\begin{array}{c}\text { Ġahan, the wise fool according to Cassar-Pullicino's (1967), } \\
\text { Attard's (1970) and Mifsud-Chircop's recorded texts }\end{array}$} \\
\hline $1-1009$ & "Pull Door Behind You" (Cassar-Pullicino 13) \\
$2-1013$ & Bathing the Child (Cassar-Pullicino 13) \\
$3-1036$ & Opening beneath Tail (Cassar-Pullicino 19) \\
$4-1037$ & Shearing the Sow (Cassar-Pullicino 15) \\
$5-1050$ & Felling a Tree (Cassar-Pullicino 19) \\
$6-1060$ & Squeezing the (Supposed) Stone (Cassar-Pullicino 19) \\
$7-1063 \mathrm{~A}$ & Throwing Contest: Trickster Shouts (Cassar-Pullicino 19)
\end{tabular}




\begin{tabular}{|l|l|}
$8-1070 \mathrm{~A}$ & Throwing Giant Himself (Cassar-Pullicino 19) \\
$9-1085$ & Pushing a Hole into a Tree (Cassar-Pullicino 19) \\
$10-1210$ & The Sow is Taken on the Roof(Cassar-Pullicino 15) \\
$11-1386$ & Meat as Food for Cabbage (Cassar-Pullicino 15) \\
$12-1539$ & Cleverness and Gullibility (Attard 1, Cassar-Pullicino 18, Mifsud- \\
& Chircop 70) \\
$13-1558$ & Welcome to the Clothes (Mifsud-Chircop 38) \\
$14-1592 \mathrm{~B}$ & The Pot has a Child and Dies (Cassar-Pullicino 17) \\
$15-1655$ & The Profitable Exchange (Cassar-Pullicino 16) \\
$16-1693$ & Where People Do not Sit (Cassar-Pullicino 14) \\
$17-1696$ & Literally Followed Instructions (Cassar-Pullicino 16) \\
\hline
\end{tabular}

books Gahan has always been projected as a stupid boy. Moreover, one of the co-authors of the comedy $\dot{G}$ ahan (1995) might not have been au courant with my research, for in his promotion leaflet he defines my Ġahan stories as bluhat ('stupidities'). However, the authors make full use of what is made of my same plots, characterisation and narrative sequence, without acknowledging the source, to prove, according to one of the authors, that [t]here are further dimensions of this character which make a hero of him! $!^{10}$

\section{ADULT ĠAFAN AND VARIANTS}

Similarly with Xuereb who is completely mistaken and not au courant with Maltese folk narrative research and fails to understand the importance of variants, Gużè Cassar-Pullicino had already published his text on adult Ǵa han in his Stejjer ta' Niesna (Tales of Our People) (Malta, 1967, no. 18) which features ATU 1539. My video recording of "Ǵa han u 1-Ghasel" (Ġahan and the Honey), a text from Żejtun featuring adult Gahan, ${ }^{11}$ is another confirmation and contradicts Xuereb's words. The video interview, recorded on 28 August 1997, has been transmitted in Malta on a popular Maltese television station in the author's ethnographic series Fuq Ghajnejk ['Crafts in Improvisation', 15 March 2001]. The data represents and interprets a living community, understanding the nature of Gahan, locally conceived as an anti-hero in a recorded Maltese ethnopoetic text. ${ }^{12}$

\section{A QUESTION OF GENRES}

Another blatant example of gross misinterpretations on Gahan is found in The Malta Stamp Official Bulletin of the Philatelic Bureau Europa '97, No. 154, published in May 1997. My first objection goes to the ambiguity in genre and 
sub-genre treatment where no distinction is made between fairytales, anecdotes, legends, etc.

Maltese folklore grew so rich in traditions and legends as to form an important aspect of our national identity. The typical characters in these legends and their involvement in the story is [sic] a living reflection of our chequered history dominated by events in the Mediterranean area of the time. These legends are still popular with the present generation (The Malta Stamp Official Bulletin of the Philatelic Bureau Europa '97, 1997). ${ }^{13}$

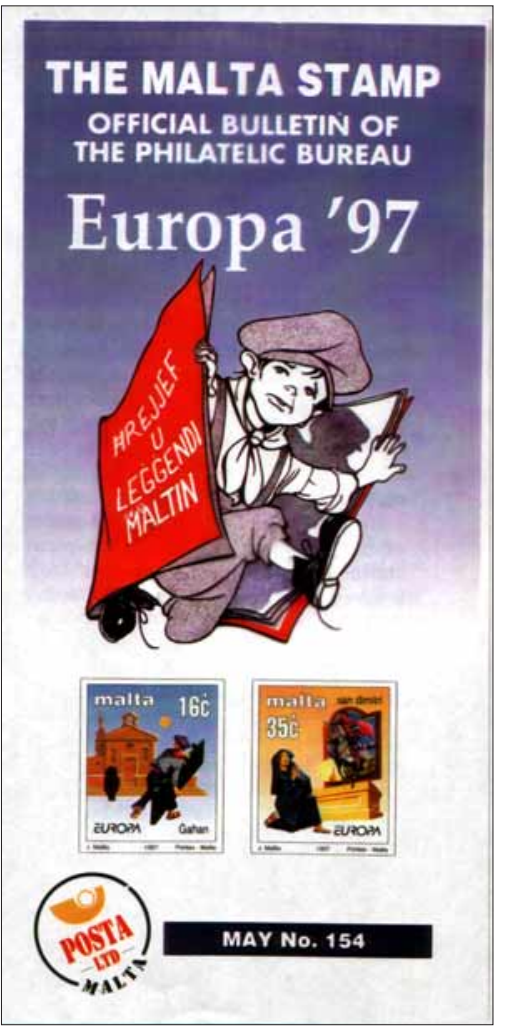

Figure 9. The Malta Stamp Official Bulletin, May 1997.

The Gahan 'story' illustrated on one of the Malta stamps, is ATU 1009 ("Pull door behind you!") ${ }^{\mathbf{1 4}}$ and this is a humorous anecdote, as corrected in the third paragraph of the Bulletin, but definitely not a legend. Narratives are "attractive" to all generations, and not, as implied, only "to young minds" and "many Maltese children". It is a living experience during my direct field research and active participation in Malta and Gozo, where adults (middle-aged and old men and women alike) enjoy narrating all genres of stories, memorata included, to one another and to outsiders. This identification of Gahan as "light-headed" destroys the full perspective of this Maltese anti-hero.

Gużè Chetcuti's translation of Aldo Farini's Fiabe, leggende e tradizioni maltesi (19341936), published up till now in two volumes Frejjef ta' Gahan u Stejjer Ohra (Ġahan Tales and Other Stories, 1997) and Ghar Hassan u Hrejjef Otra (Ghar Hassan and Other Tales, 1998), features Maltese popular narratives; conspicuously among them a number of Gahan texts. Farini a.k.a. Arnaldo Fabriani designed his work to incorporate Maltese folklore and local perceptions of identity as regional variations within a wider Italian framework. ${ }^{15}$ Farini had already been partially translated and serialized by T. Mifsud in a local newspaper in 1970, and printed in book form in $1972 .{ }^{16}$ The frequent translation, reproduction and publishing of old texts and their varieties point to a lack of field research and, in the Malta case, inertia in researching the Melitensia sections of local librar- 
ies and consulting the latest academic publications by foreign and Maltese folklorists. ${ }^{17}$ In the promotional pre-publication material published during the Christmas season on various newspapers, the same anonymous writer reaches the highest limits of absurdity

For the first time the Ga han tales are being published in full and undiluted as they were originally narrated by our ancestors about a century ago...

These tales were mostly narrated during Christmas time, when older people used to gather their children around the crib and in the lamplight or candlelight [and] children used to relish listening to Ga han's tales (Kull Fadd 1997: 4). ${ }^{18}$

While this quote typifies the static perspective Maltese writers have of our narrative, it is not known that the Gahan tales were narrated only during the Christmas season. Moreover, Chetcuti's (and Mifsud's) work should be better defined as an example of back translation, as Farini himself had already undertaken the first "mental" translation with his various Maltese informants, secondary school students included. Such a procedure does not give us the proper semantic information about our native culture.

\section{ĠAHAN'S FORMA MENTIS}

Maltese ethno-poetic texts identify Gahan with the numskull, in others he is the Maltese wise fool, artificially indulging in anti-social behaviour, but in his comedy he also takes the role of a social critic reprimanding negative behaviour, of an interceder for the injured and the insulted (see Tables 1, 6-7). This is the Gahan of my publications and studies. He is a poetic vehicle to express folk wisdom, often putting on himself the fool's cap. His tales are a kind of "ritual of rebellion" which represents an institutionalized way of expressing the antagonism towards authority. Gahan's anecdotes, jests, and facetiae constitute the temporary subversion of a conscious, symbolic order in the interests of a pleasure-oriented subconscious.

In a praspura ta' Ga han anything can happen: sentimentality, fantasy, obscenity, satire, perversion, religion, politics, social change, crime, fear, punishment, death, and numerous other themes find expression. They are like screens upon which the narrators project their culture's patterns and their own innermost thoughts, an important mechanism to reveal problem areas and release tensions. Things may be said and described in a praspura which are intolerable in most actual social situations. Things happen in the Gahan cycle that never 
occur in real life. Within the fairly strict formal boundaries of the anecdote of one basic episode, two or three characters, and a single problem-resolution structure, there may be the greatest freedom of language and detail. In some way or other something in the infinite play of events subverts an element of the established order of society. The anecdote is sense-in-non-sense, incongruity being the defining feature. The shared pleasure of the anecdote is the incarnation of a dimension of sociality, actualising community. By the same token some Gahan tales are censored when the transgression involved is inappropriate and disruptive, so that by sharing revulsion and refusal society is giving vent to another basis of community and they cease to be a pleasurable subversion, defined instead as a social anathema.

The comic aspect can be rooted in certain features of the social context itself and in knowledge of presuppositions given to the members of the community. The world built in our text is enormously different from the real world and the distance between them is truly measured by laughter at the conflict of the different worlds, the discrepancy between the real world and the world created by the text. The illogic world built up "logically" and the true statements in the text are ridiculously false from the point of view of the real world of the audience. Gahan destroys the logical world by his illogical, comic philosophy to build up another reality and make the illogical world be just and logical.

Gahan's praspar always have a butt, even though the 'victim' may sometimes be himself or an idea rather than an individual. In the Maltese context we have to assume that the victim of Gahan is not only himself, the idea or the value in question, but his audience who believes in the idea in question. Here the implications underscore banality, both the centrality of the discoursive and the pragmatic dimensions of meaning, and the relative marginalisation of the semantic and grammatical dimensions. Disagreement about meaning in Gahan's praspar is fundamental to the construction of the anecdotes, in the sense that the possibility of disagreement is central.

\section{COMMENTS}

1 Type numbers ATU follow Uther 2004. Asterisks preceding type numbers follow Mifsud-Chircop 1978.

${ }^{2}$ According to Joseph Zammit-Mangion, Laferla is still considered as one of the greatest directors of Maltese education (1998: 14).

${ }^{3}$ Zammit-Mangion briefly describes the historical process: English and Maltese, in this order, became the official languages of these Islands. Maltese replaced Italian in the elementary schools and a new orthography, that launched by the Ghaqda tal-Kittieba 
tal-Malti (1921) through its Taghrif fuq il-Kitba Maltija of 1925, became the official orthography of the language. This entailed the compilation of new Maltese readers based on the new orthography and new methods of instruction ..., the introduction of a new grammar and language textbook ..., and the translation into Maltese of Geography and History textbooks...(1992: 53).

${ }^{4}$ According to David Marshall (1971: 68, see also: 111), this was a post which $D r$ Laferla ... had created specially for him in order to enable him to help the cause of the Maltese Language.

${ }^{5}$ One witness told the 1931 Royal Commission about an ultra-Nationalist Franciscan, Fr Luigi Attard, who had given a lecture at the Unione Cattolica San Giuseppe in which he applied Aristotle's division of society into the well-to-do and slaves, mutatis mutandis, to the Malta of his day (see Hull 1993: 255).

6 An excerpt from a dialogue between two pupils Salvu and Karmnu runs: "I got to know that long ago my father saw the Queen". "One can imagine what pleasure and happiness it must have been to see the queen of this country!" "Long live the Queen! Long live the Queen!" (In Maltese: "Sirt nafli, wisq ilu, il-pa ra lir-Regina". "Mur ara, kemm ferhu gost tara lir-Regina ta' din l-art!" "Viva r-Regina! Viva r-Regina!”).

7 Non-governmental schools introduced in $I l$-Gojjin [The Linnet] series ( 7 vols., 1984 1986), edited by Tony C. Cutajar, where no reference is made to any Gahan anecdotes.

${ }^{8}$ In this anthology there are other types in various texts which belong to the same antiheroic cycle, although Gahan is not mentioned by name (see Mifsud-Chircop 1978).

${ }^{9}$ Roman numbers refer to volume, followed by page numbers.

${ }^{10}$ In the original: Hemm ukoll dimensjonijiet ohra ta' dan il-persunagg li jistghu jaghmluh eroj (author's emphasis).

Although a full third of the play was literally lifted from my book, acknowledgements of my_adan tales were not made before or during the two dramatic representations. Full use of my work was acknowledged following my protestations with Rainbow Productions Ltd, the organisers, chaired by the then Leader of the Opposition, Dr Alfred Sant. His secretary and Programmes Manager for Super One Television, Joe Borg, confirmed in writing

Nirreferi ghall-ittra tieghek lil Dr Alfred Sant datata [sic] 2 ta’ Gunju 1996.

Ninfurmak li 'Gahan' se tintwera [sic] fuq Super One Television nhar il-Hadd 16 ta' Gunju fis-2.00 ta' wara nofs in-nhar u li qabel jintwera se jinqara dan il-kliem: "Il-praspar u l-hrejjef tradizzjonali ta' Gahan li qed jissemmew ittieћdu millktieb Gahan u Hrejjef Ohra (1992) ta' Gorg Mifsud-Chircop, pubblikazzjoni talPublishers Enterprises Group (P.E.G.) Ltd ta' San Giwann."

["With reference to your letter to Dr Alfred Sant dated 2 June 1996.

I am informing you that Gahan will be screened on Super One Television on Sunday 16 June at 2.00 p.m., preceded by the reading of the following words: The Gahan anecdotes and tales which are being mentioned have been taken from Gahan u Hrejjef Otra (1992) by Ġorg Mifsud-Chircop, publication Publishers Enterprises Group (P.E.G.) Ltd of San Gwann."] 
11 The false idea that Gahan tales are extinct in Malta and Gozo has been repeatedly asserted in the local press. Doris Vella, the compiler of Il-Ga han ta' Madwarna (The Gahan around Us, 1995), and author of a letter entitled "Cherishing our Folklore", The Times [of Malta], 24 May 1998, unfairly claims that Gahan, who has ruled over the Mediterranean countries from Morocco to the Far East, north and south, has become a relic of the past. Our sophisticated mind has deemed him an idiot and relegated him to obscurity. See also the introduction to her book (Vella 1995: v), where she redraws the same erroneous conclusions.

${ }^{12}$ My narrator, ninety-year old Angla Mifsud, nicknamed Ić- Calija, of Żejtun Malta, is an accomplished raconteur and folk-singer, with a remarkable gift of speech, a colourful personality, and a most vivid imagination. Her Gahan narrative is a multiepisodic tale, and though Stith Thompson (1946: 10, 22, 216-217) might have defined it as formally vague, indifferently performed and submit itself "only imperfectly" to the processes of oral folktale tradition and do "not require any great skill or memory", yet the degree Angla and other Maltese natives recognize and appreciate her stylistic dimensions in her examples of oral texts and performances command keen attention. It is no wonder that Angla has narrated to me majestic magic tales with the same narrative keenness, involvement, delight and pleasure, even when I turned up on more than one occasion to have her retell an "old one" for my current study of her personality in action vis-à-vis creativity and spontaneity, individuality and idiosyncrasy, innovation and improvisation. Her individuality in selecting and narrating a given anecdote is second to none. Her power to narrate is fascinating, and she simultaneously acquires power through the creation of pleasure in her listeners. The narrative falls under the international title "Cleverness and Gullibility" (ATU 1539). It is her favourite anecdote, demanding certain devices of performance that coincide with her talent. During her narrative one feels she is drawing upon assorted improvisory techniques, including lengthening and shortening, using or eliminating repetition, extended characterization, dialogue and description, skilled dramatic performance replete with proxemics, gestures, vocal effects, facial expressions, and body movement.

${ }^{13}$ (Author's emphasis). The nauseating confusion in the careless use of scientific tropes in Malta is especially irritating in Gużè Chetcuti's notes to his translation of Aldo Farini's anthology Fiabe, leggende e tradizioni maltesi. He has lately persisted in regarding 'fairytale' (Maltese $\hbar r a f a$ ) and 'legend' (Maltese le ggenda) as synonymous: ... Fil-fatt, bejn wiehed u iehor, il-grajja tista' tkun tal-wiehed u tista' tkun ta' l-ohra [i.e., tal-hrafa u tal-leggenda]. [Transl. In fact, the story may belong by and large to either genre [i.e., to either fairytale or legend.) See G. Chetcuti, "Hrejjef u Leggendi...," IlMument [The Moment], 17 Jan 1999; see also my various comments in The Malta Independent on Sunday, "Gallarija”, 13 Dec 98, The Sunday Times [of Malta], 13 Dec 98, Kull Hadd [Every Sunday], 13 Dec 98, and "It-Testi ta' Aldo Farini - Żbalji u Mhux Polemiki" [Aldo Farini's Texts - Mistakes not Polemics], Il-Mument [The Moment], 12 Feb 1999.

${ }^{14}$ AT references according to Mifsud-Chircop 1978.

${ }^{15}$ On the part Malta played within the fascist regime's programme to expand its dominion in the Mediterranean Sea to make it an "Italian lake", see W. E. Simeone 1978: 553, 555, 557; Clews is of the opinion that Farini culled a good amount of his raw material from his secondary school pupils, Clews being one of them: 
It-taghrif kollu li kien irnexxielu jikseb fuq Malta, il-Professur Fabriani kellu tattika kbira kif jigbru. Jiena niftakru li lilna kien jaghtina komponimenti li ssuggetti taghhom kienu jkunu nghidu ahna 'Kamra ta' 1-Ikel Maltija,' 'Kc̈ina Maltija,' 'Il-Kamra tas-Sodda Tieghi.' Kollox kien ikun irid bit-Taljan, deskrizzjonijiet, nghidu a tna bini ta' sentenzi, imma u din kienet ghalih importanti, kien irid ismijiet ta' oggetti, ghamara, ećc. bl-ismijiet Maltin.

[Transl: Prof. Fabriani had a great ability to extract all the information which he managed to obtain on Malta. I remember him setting essays to us on topics such as 'A Maltese Room', 'A Maltese Kitchen', 'My Bedroom'. He would want everything written in Italian - descriptions [and] sentence structure. However, and this was important for him, he expected names of items, furniture, etc. to be written in Maltese (emphasis in the original, Clews 1998).]

16 The book also incorporates Il-Grajjiet ta' Gahan "Nawadir Goha" (The Anecdotes of Gahan "Nawadir Goha"), 94 anecdotes translated from the Arabic by F. Debarro.

17 The latest case in point is Chetcuti's failure to consult various studies, including Galley 1971: 64-70, and my publications Mifsud-Chircop 1980, 1981, 1982, 1991. His preposterous assertions on my Hrejjef ta' Ga han u Stejjer Ohra include: (1) folkloristic texts are primarily addressed towards the learning and practising reading in Maltese (... [il]-qarrejja, b'mod specjali [l-]istudenti ... ghandhom isibu f'dawn il-hrejjef u leggendi sodisfazzjon u pjacir imma, aktar minn hekk, taghlim u tafrig fil-qari ta' 1ilsien Malti. [Transl:. '... Readers, students in particular, should discover in these folktales and legends satisfaction and pleasure but, more than this, the learning and practice of reading in Maltese'.] - this is repeated on the back cover; (2) Cortis includes legends in his collection of anecdotes - this absurdity is perpetuated by other writers, including Vella 1997; (3) the present writer modelled his narrative treatment in the 1992/95 anthology on Farini's; (4) the Gahan anecdotes are on the verge of extinction in Malta; (5) the impression that Cortis (1856-1916) copied Farini's literary rendition in Italian (1933-36), thus reversing the chronological sequence of events, viz. Farini included various tales by Magri, along with stories culled from the collections of [Hans] Stumme, [Luigi] Bonelli and other writers such as Dun Xand Cortis. (See also Cassar-Pullicino 1963: 144.)

${ }^{18}$ In Maltese original:

“Ghall-ewwel darba, il-hrejjefta' Ga han se jidhru shahu intatti kif rakkontati [sic] originarjament mix-xjuhtag tna sa daqs seklu ilu...

L-iktar li kienu jigu rrakkontati dawn il-hrejjef kien fi żmien il-Milied, metaxxjuћkienu jigbru liż-żghar hdejn il-presepju u fid-dawl tal-lampa jew tax-xemgha, it-tfal kienu joghxew jisimg hu 1-istejjer ... [ta'] Gahan...”

See also "Ga han fi żmien il-Milied" [Ġahan during the Christmas Season], Kull Hadd 1997; It-Torca 1997; Il-Mument Pizzikanna 1998; and The Times [of Malta] 1997.

\section{REFERENCES}

Aarne, Antti \& Thompson, Stith 1961. The Types of the Folktale. A Classification and Bibliography. Second Revision. FFC 184. Helsinki. 
Attard, Anton F. 1970. Hrejjef minn Ghawdex. [Tales from Gozo.] It-Tromba, 5 July26 Sept.

Bonelli, Luigi 1895. Saggi del folklore dell'isola di Malta. Palermo: Giornale de Sicilia.

Bonelli, Luigi 1897. Il dialetto maltese. Archivio glottologico italiano, Supplemento Period, No. 4, pp. 53-98.

Bonelli, Luigi 1899. Il dialetto maltese. Archivio glottologico italiano, Supplemento Period, No. 6, pp. 37-70.

Briffa, Charles 2002. Il-Gahan ta' Bingemma. Edited by Francis Ebejer. Critical 3rd ed. Malta: Klabb Kotba Maltin.

Camilleri, J. J., Fenech, V. \& Mifsud, P. 1974. Id-Denfil. Malta: Id-Dipartiment ta' lEdukazzjoni.

Cassar-Pullicino, Joseph 1963. Folk-Narrative Research in Malta since the War. Maltese Folklore Review. Vol. 1/2, pp. 1-2.

Chetcuti, Gużè 1997. Hrejjef ta' Gahan u Hrejjef Otra [Ġahan Tales and Other Stories.] Vol. 1. Malta: Marsa Press, Sensiela Kotba Socjalisti.

Chetcuti, Gużè 1998. Ghar Hassan u Hrejjef Ohra. Ghar Hassan and Other Fairytales.] Vol. 2. Malta: Marsa, Sensiela Kotba Socjalisti.

Chetcuti, Gużè 1999. Hrejjef u Leġgendi... [Tales and Legends], Il-Mument, 17 Jan.

Clews, Charles 1998. Il-Professur Fabriani. [Professor Fabriani.], It-Torca Magazin, 11 Jan.

Cutajar, Tony C. (ed.) 1984-1986. Il-Gojjin [The Linnet]. 7 vols. Malta: Falcon Educational Books.

Cutajar, Tony C. (ed.) 2002. Gojjin Ieћor [Another Linnet]. It-Tmien Ktieb [Book Eight]. Malta: De La Salle Brothers Publications.

Cutajar, Tony C. (ed.) 2004. Gojjin Iehor [Another Linnet]. Is-Seba' Ktieb [Book Seven]. Malta: De La Salle Brothers Publications.

Ebejer, Francis 1985. Il-Gahan ta'Bingemma u Drammi Ohra. Dramm-Saga fi Tliet Atti. Malta: Il-Ministeru ta' l-Edukazzjoni.

Ebejer, Francis 1989. The Bilingual Writer (Mediterranean-Maltese and English) as Janus. Malta: The Foundation of International Studies.

Farini, Aldo [Arnaldo Fabriani] 1934-1936. Fiabe, leggende e tradizioni maltesi. 3 vols. Malta: Casa S. Giuseppe.

Fenech, Victor et al., (eds.) 1981. Id-Denfil. Vols 4-6. 2nd revised ed. Malta: IdDipartiment ta' l-Edukazzjoni; 3rd ed. Malta: Id-Dipartiment ta' l-Edukazzjoni (1985).

Fenech, Victor 1976. A Bibliography of Children's Literature in Malta 1966-1976. Malta: Malta Library Association.

Fenech, Victor 2003. Il-Ktieb Malti. [The Maltese Book.] Kullana Kulturali 55. Malta: Pubblikazzjonijiet Indipendenza.

Galea, Mary Josephine 1976. Gorg Pisani Poeta. BA (Hons.) thesis. Malta: Malta University of Malta.

Hull, Geoffrey 1993. The Malta Language Question. A Case Study in Cultural Imperialism. Malta: Said International Ltd.

Ilg (Köbler-Ilg), Bertha 1906. Maltesische Märchen und Schwänke. 2 vols. Leipzig: J. C. Hinrichs'sche Buchhandlung. 
Ilg (Köbler-Ilg), Bertha 1995. Kemużell. The Maltese Practical Joker. Transl. by Rev. J. M. Milne. Edited with an introduction by J. Cassar-Pullicino. Malta: Publishers Enterprises Group.

Marshall, David 1971. History of the Maltese Language in Local Education. Malta: Malta University Press.

Mifsud, T. 1972. Hrejjef ta' Ga han u Hrejjef Ohra [Ġahan Tales and Others]. Translation. Malta: Stamperija Il-Hajja.

Mifsud-Chircop, George/Gorg 1978. Type Index of the Maltese Folktale in the Mediterranean Tradition Area. MA thesis. Malta: University of Malta.

Mifsud-Chircop, George/Ġorg 1980. Il-Praspar ta' Ga han. Malta: Gulf Publishing.

Mifsud-Chircop, George/Ġorg 1981. Gahan u l-Ggant Gulija. [Ġahan and Giant Goliath.] Malta: Gulf Publishing.

Mifsud-Chircop, George/Gorg 1983. Aktar mill-Praspar ta' Gahan. [More Gahan Anecdotes.] Malta: Gulf Publishing.

Mifsud-Chircop, George/Gorg 1991. Il-Praspar Miktuba minn Dun Xand Cortis [The Written Anecdotes by Rev. Xand Cortis]. Malta: Publishers Enterprises Group.

Mifsud-Chircop, George/Gorg 1992. Ga han u Hrejjef Otra. Malta: Publishers Enterprises Group.

Mifsud-Chircop, George/Ġorg 1999. It-Testi ta' Aldo Farini - Żbalji u Mhux Polemiki. [Aldo Farini's Texts - Mistakes and No Polemics]. Il-Mument, 12 Feb.

Mifsud-Chircop, George/Gorg 2001a. Mill-Praspar ta' Ga Łan u Stejjer Tradizzjonali Maltin Otra. Malta: Publishers Enterprises Group.

Mifsud-Chircop, George/Gorg 2001b. The Maltese Heroic Folktale. PHD thesis. Malta: University of Malta.

Mifsud-Chircop, George/Ġorg 2005. Gahan fid-Dramm ta' Ebejer u n-Narrattiva Folkloristika. Fora Melitensia, Vol. 2, Malta: l-Università ta' Malta, id-Dipartiment tal-Malti, Junior College, pp. 26-38.

Puli, Mary C. et al. (eds.) 1974. Id-Denfil. Taż-Żghar and vols 1-3. 1st ed. Malta: Id-Dipartiment ta' l-Edukazzjoni; 1981. 2nd revised ed. Malta: Id-Dipartiment ta' l-Edukazzjoni.

Stumme, Hans 1904a. Maltesische Studien: eine sammlung prosaischer und poetischer Texte in Maltesischer Sprache. Leipzig: J. C. Hinrichs'sche Buchhandlung.

Stumme, Hans 1904b. Maltesische Märchen, Gedichte und Rätsel in Deutscher Übersetzung. Leipzig: J. C. Hinrichs'sche Buchhandlung.

Thompson, Stith. 1946. The Folktale. New York: The Dryden Press Inc.

Uther, Hans-Jörg 2004. The Types of International Folktales. A Classification and Bibliography. 3 vols. Helsinki: FFC.

Vella, Doris 1995. Il-Gahan ta' Madwarna. [The Gahan around Us.] Malta: Malta Union of Teachers.

Vella, Doris 1998. Cherishing our Folklore. The Times [of Malta], 24 May.

Vella, E. B. 1934. Gabra ta' Ward [A Collection of Roses.] L-Ewwel Ktieb. London: Oxford University Press.

Vella, E. B. 1935. Gabra ta' Ward. It-Tieni Ktieb. London: Oxford University Press. Vella, E. B. 1936a. Gabra ta' Ward. Ir-Raba' Ktieb. London: Oxford University Press. Vella, E. B. 1936b. Gabra ta' Ward. It-Tielet Ktieb. London: Oxford University Press. Vella, E. B. 1936c. Gabra ta' Ward. It-Tieni Sena. London: Oxford University Press. 
Vella, E. B. 1936d. Gabra ta' Ward. L-Ewwel Sena. London: Oxford University Press. Vella, Mario 1997. Gahan Paints the Town Red. The Sunday Times [of Malta], 21 Dec.

Zammit-Mangion, Joseph 1992. Education in Malta. Malta: Studia Editions.

Zammit-Mangion, Joseph 1998. The Great Educationalists. Albert V. Laferla. The Teacher, 71, pp. 14-15.

Zammit-Mangion, Joseph 2000. L-Istorja ta' l-Edukazzjoni f'Malta. [The History of Education in Malta.] Kullana Kulturali, No. 20. Malta: Pubblikazzjonijiet Indipendenza, pp. 79-81. 